\title{
Usage of brown algae Padina pavonica and Turbinaria decurrens to control bacterial brown rot disease
}

\author{
Rabab, M. Abd- El-Aziz \\ Bacterial Diseases Research Department, Plant Pathology Research Institute, \\ Agricultural Research Center, Giza, Egypt. \\ Corresponding author: Rab.m.sultan@gmail.com
}

\section{$\underline{\text { Abstract }}$}

Brown algae contain the highest biological activities and considered an important source of bioactive natural substances. Two algae (Padina pavonica and Turbinaria decurrens) extracted by two solvent (water and ethanol) used to study their antibacterial activity on development brown rot disease in vitro and under artificial inoculation condition. The two algae ( $P$. pavonica and $T$. decurrens) inhibited the growth of Ralstonia solanacearum in vitro. The highest inhibition zone recorded with $P$. pavonica water extraction and the least one was $T$. decurrens ethanol extraction. Two algae extraction decreased area under disease progress curve (AUDPC) and disease severity in all treatments compared with the positive control. Quantity of total and free phenols increasing to reach high amount in $P$. pavonica water and ethanol extractions compared with $T$. decurrens extractions. The suppuration of $R$. solanacearum and its disease severity affected by the kind of extraction solvent used in the extraction of algae and the amount of total and free phenols for each alga. Water and ethanol extraction of $P$. pavonica was more effectiveness in controlling $R$. solanacearum in vitro and under artificial inoculation condition. Further research aiming to identify the specific phenolic compounds which are responsible for higher antibacterial activity and availability of apply the algae in controlling plant diseases.

Keywords: Brown algae, Ralstonia solanacearum, Padina pavonica, Turbinaria decurrens, Brown rot disease. 


\section{$\underline{\text { Introduction }}$}

Ralstonia solanacearum is the causal agent of bacterial wilt ( brown rot) disease in hundreds of economic plants from different families. Bacterial wilt is more important in temperate region according to quarantine status than yield loss (Hayward, 1991). This pathogen is the most common pathogen that affects the exportation of potato crop, especially to the European markets and lead to loss of money (Kabeil et al., 2008).

Difficulties are associated with controlling $R$. solanacearum due to its abilities to grow endophytically, survive in soil, especially in the deeper layers, travel along water, and its relationship with weeds. So, Yuliar $\boldsymbol{e t}$ al., (2015) discuses different diverse options have been reported on control methods against diseases caused by $R$. solanacearum and shows some solutions (eg. integrating a biological control agent and organic matter including simple organic compounds, compost, or plant residue).

Marine algae are one of the largest producers of biomass in the marine environment. They produce a wide variety of chemically active metabolites in their surroundings. These active metabolites, also known as biogenic compounds, produced by several species of marine macro and micro algae, have anti-bacterial, anti-algal, anti-macrofouling and antifungal properties, and have other likely uses, e.g. in therapeutics (Bhadury and Wright, 2004).

Macroalgae considered a big source of potential compounds useful for controlling new diseases or multi-resistant strains of pathogenic microorganisms such as bacteria, fungus and virus (Pérez et al., 2016). Marine algal species have some compounds like sterols, Polysaccharides, peptides, proteins, vitamins, chlorophyllides, phenols, heterocyclic 
compounds, halogenated ketones, alkanes and cyclic polysulphides (Mtolera and Semesi, 1996., and Abdel-Raouf et al., 2015). In recent year, seaweeds are used in several applications such as anti-microbial (Chiheb et al., 2011). In Egypt, Farag et al., (2017) proved the suppression effect of seaweed extract (SWE) on $R$. solanacearum whereas increase nutrient uptake and improve crop productivity.

Turbinaria decurrens algae extracts shows presence of alkaloids, terpenes, phenols, tannins, saponins, flavonoids, quinones, proteins, sugars, carbohydrates, alkaloids, coumarins, steroids terpenoids and cardiac glycosides, so it used in many branches: antimicrobial, antidiabetic, antioxidant, hepatoprotective, antifungal, antitumor, anticoagulant, and antibacterial (Deepak et al., 2017). Whereas, brown algae Padina pavonica is an important one, extensively used as a feedstock for the production of bio-diesel, in heavy-metal bio-sorption, as a pollution bio-indicator, a trace metal bio-monitor, an anti-oxidant, an anti-cancer drug (by inducing apoptosis of cancer cells), an anti-bacterial agent and a bio-insecticide (El Maghraby and Fakhry, 2014).

This study aimed to evaluate the efficacy of two brown algae against $R$. solanacearum in vitro and their ability to reduce the development of brown rot disease under greenhouse conditions.

\section{Materials and Methods}

\section{Source of algae:}

Two algae (Turbinaria decurrens and Padina pavonica) and their extractions were obtained kindly from National Institute of Marine Science and Fisheries, Hurghada, Red Sea Governorate, and Environmental Biotechnology Department, College of Biotechnology, Misr University for Science and Technology. 


\section{Source of $R$. solanacearum isolate:}

Virulent isolate of $R$. solanacearum was obtained from the collection of Bacterial Diseases Research Department, Plant Pathology Research Institute, ARC, Giza, Egypt. Virulent isolate was previously isolated from infected potato tubers and was identified using Immunofluorescent Antibody Staining (IFAS) and PCR technique using specific primer (Shoala and Abd-El-Aziz, 2019).

\section{Effect of two algae on $R$. solanacearum in vitro:}

Algae (P. pavonica and T. decurrens) extracted with cold water and ethanol screened for their ability to inhibition $R$. solanacearum growth by two methods (Stonier, 1960) as the following.

(1)Papers discs:

Plates containing triphenyle tetrazolium chloride (TTC) medium seeded with $R$. solanacearum isolate using appropriate amount of broth culture ( $3 \mathrm{ml}$ of $10^{8}$ colony forming units (cfu) $/ \mathrm{ml}$ suspension for flask containing $250 \mathrm{ml}$ medium) as inoculum. Discs of sterilized filter paper (whatman3) were immersed in each concentration of algae extractions ( 1 and $2 \mathrm{ml} / 250 \mathrm{ml}$ water). Three plates were designated for each treatment (have discs immersed in algae extractions). Three plates have discs immersed in ethanol only and water as a negative control. All plates incubated for $48 \mathrm{hrs}$ at $28^{\circ} \mathrm{C}$ and inhibition zone was measured.

(2)Dilution Plates:

Plates containing King's B (KB) medium have algae (1 and $2 \mathrm{ml}$ $1250 \mathrm{ml}$ medium). Other plates have KB medium with ethanol and other containing KB medium only (negative control). A loopful of $R$. solanacearum (24 hrs- old) streaked on surface of each plate. Three plates Page 4 of 18 
were designated for each treatment. All plates incubated for $48 \mathrm{hrs}$ at $28^{\circ} \mathrm{C}$, then observed the growth of bacteria on plates surface.

\section{Effect of two algae on disease severity under artificial inoculation condition:}

A suspension of bacterial isolate was prepared by inoculation in nutrient agar (NG) broth and incubated at $28^{\circ} \mathrm{C}$ for $48 \mathrm{hrs}$ and adjusted to $10^{8} \mathrm{cfu} / \mathrm{ml}$. Pots $(20 \mathrm{~cm}$ diameter) filled with sterilized soil and irrigate by water before $24 \mathrm{hrs}$ from infestation with $R$. solanecearum. Tomato seedlings (cultivar Beto 86 and 28 day-old) were soaked for one hour in algae suspension ( 1 and $2 \mathrm{ml}$ from each alga / 250ml water) before transplanting in infested soil. Tomato seedlings soaked in water only before transplanted (as negative control) and other seedlings transplanted directly in infested pots (as positive control). Ten replicates were used for each treatment. Disease incidence was represented by measuring AUDPC which were calculated according to percentage of wilted leaves progress per plant overtime (Winstead and Kelman, 1952. and Messiha, 2006). The disease severity (DS) was recorded after 21 days from sowing in infested soil, where DS was calculated as the following:

Disease Severity $(\%)=[\Sigma(\mathrm{ni} \times \mathrm{vi}) \div(\mathrm{V} \times \mathrm{N})] \times 100$ ni=number of plants representing each disease rating; vi=disease rating; $\mathrm{V}=$ the highest disease rating (5); and $\mathrm{N}=$ total number of plants. Disease rating was calculated as following scale: $0=$ no symptoms, $1=$ one-two leaves wilted, $2=$ three or four leaves wilted, $3=$ most leaves wilted, $4=$ all leaves wilted and 5=whole plant died. (Winstead and Kelman 1952).

\section{Statistical analysis:}

Completely randomized design was used in all experiments. The collected data were analyzed using one-way ANOVA as outlined by (Gomez and Gomez, 1984). For preforming the mentioned statistical 
analysis, SPSS version 13.0 (SPSS Inc., Chicago, IL, USA) statistical packages were used. Duncan's multiple range test (Duncan, 1955) was used to compare the means at probability $(P)$ level 0.05 .

\section{Activity of phenolic compounds from algae:}

\section{A- Phenolic Extraction:}

Algae were extracted with water or ethanol. The dried residue was dissolved in isopropanol $50 \%$ and kept in freezer till analysis. The extracts were used, later for analysis of phenols.

\section{B- Determination of total and free Phenolic:}

To determine the content of total and free phenolics the FolinCiocalteu method was used (Simons and Ross, 1971). To an aliquot of the extract, diluted Folin-Ciocalteu reagent was added. Then, to each sample, sodium carbonate (20\%) and water were added. Total and free phenolic content was measured spectrophotometrically at $520 \mathrm{~nm}$, using chatichole as standard.

\section{$\underline{\text { Results }}$}

Effect of two algae on the growth of $R$. solanacearum in vitro:

Data in Table (1) and figure (1) showed that the two extractions of two algae can inhibit $R$. solanacearum growth on TTC medium. Whereas, the highest inhibition zone recorded with water extraction of $P$. pavonica (24and $21 \mathrm{~mm}$ ) followed with $T$. decurrens (21and $19 \mathrm{~mm}$ ) at concentration 2 and $1 \mathrm{ml}$ from each alga / 250ml water. Inhibition zone was 15 and $12 \mathrm{~mm}$ with $P$. pavonica and the least one is $T$. decurrens 13and $11 \mathrm{~mm}$ with ethanol extraction at concentration 2 and $1 \mathrm{ml}$ from each alga / $250 \mathrm{ml}$ water respectively. Although, inhibition zone was zero when used ethanol or water only. 
Table (1): Diameter of inhibition zone for different concentration of water and ethanol extraction of two algae on the growth of $R$. solanacearum in vitro.

\begin{tabular}{|c|c|c|c|}
\hline \multirow{2}{*}{ Algae } & \multirow{2}{*}{$\begin{array}{c}\text { Concentration (ml/ } \\
\text { 250ml medium) }\end{array}$} & $\begin{array}{c}\text { Diameter of inhibition zone } \\
(\mathrm{mm})\end{array}$ \\
\cline { 3 - 4 } & & Water & Ethanol $^{*}$ \\
\hline \multirow{2}{*}{ P. pavonica } & 1 & 21 & 12 \\
\cline { 2 - 4 } & 2 & 24 & 15 \\
\hline \multirow{2}{*}{ T. decurrens } & 1 & 19 & 11 \\
\cline { 2 - 4 } & 2 & 21 & 13 \\
\hline control & - & 0 & 0 \\
\hline
\end{tabular}

${ }^{*}$ Extraction type

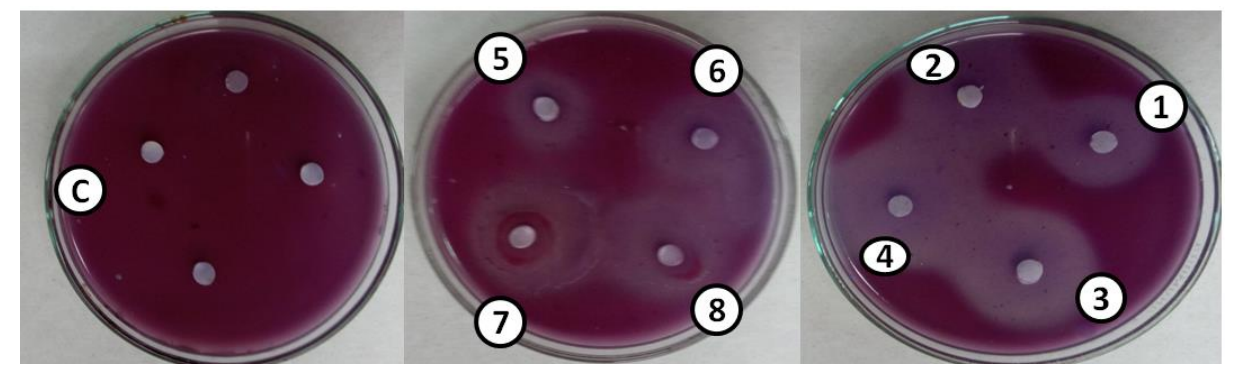

Fig (1): Inhibition zone ( $\mathrm{mm})$ of $R$. solanacearum by using water and ethanol extraction of $T$. decurrens and $P$. pavonica algae in vitro.

1: $1 \mathrm{ml} \mathrm{T}$. decurrens water extraction $/ 250 \mathrm{ml}$ water- 2: $2 \mathrm{ml} T$. decurrens water extraction $/ 250 \mathrm{ml}$ water- 3: $1 \mathrm{ml} P$. pavonica water extraction $/ 250 \mathrm{ml}$ water- 4: $2 \mathrm{ml} P$. pavonica water extraction $/ 250 \mathrm{ml}$ water- 5: $1 \mathrm{ml} T$. decurrens ethanol extraction $/ 250 \mathrm{ml}$ water- 6: $2 \mathrm{ml} \mathrm{T}$. decurrens ethanol extraction $/ 250 \mathrm{ml}$ water- 7: $1 \mathrm{ml}$ $P$. pavonica ethanol extraction $/ 250 \mathrm{ml}$ water- 8: $2 \mathrm{ml} P$. pavonica ethanol extraction/250ml water- C: Control with water and ethanol only.

On the other hand, Figure (2 and 3) showed that no growth of $R$. solanacearum observed on surface of streaked plates with the two algae in two extractions at concentration $2 \mathrm{ml}$ of algae $/ 250 \mathrm{ml}$ medium. However, in $1 \mathrm{ml}$ of algae $/ 250 \mathrm{ml}$ growth of $R$. solanacearum on surface of plate is very weak compared with control. 


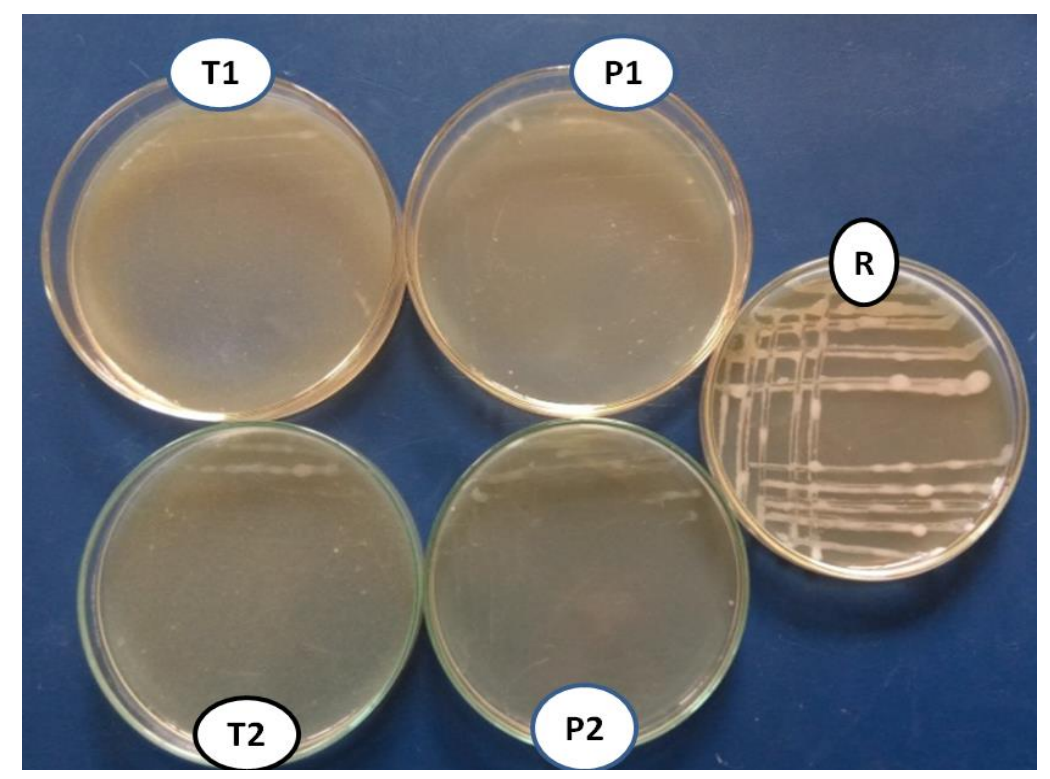

Fig. (2): Effect of water extraction for $T$. decurrens and $P$. pavonica algae on the growth of $R$. solanacearum in vitro.

T1: $2 \mathrm{ml}$ of $T$. decurrens algae $/ 250 \mathrm{ml}$ media $-\mathbf{P 1}: 2 \mathrm{ml}$ of $P$. pavonica algae $/ 250 \mathrm{ml}$ media

T2: $1 \mathrm{ml}$. decurrens algae $/ 250 \mathrm{ml}$ media - P2: $1 \mathrm{ml}$ of $P$. pavonica algae $/ 250 \mathrm{ml}$ media

R: Ralstonia solanacearum only

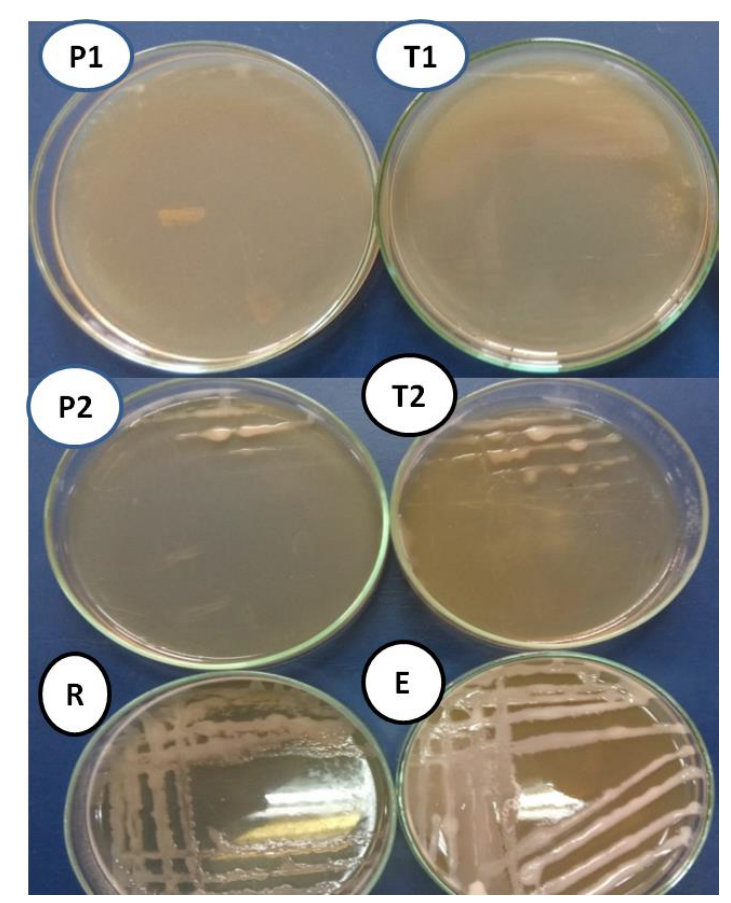

Fig. (3): Effect of ethanol extraction for $T$. decurrens and P. pavonica algae on the growth of $R$. solanacearum in vitro.

T1: $2 \mathrm{ml}$ of $T$. decurrens algae $/ 250 \mathrm{ml}$ media $-\mathbf{P 1}: 2 \mathrm{ml}$ of $P$. pavonica algae $/ 250 \mathrm{ml}$ media

T2: $1 \mathrm{ml}$. decurrens algae $/ 250 \mathrm{ml}$ media - P2: $1 \mathrm{ml}$ of $P$. pavonica algae $/ 250 \mathrm{ml}$ media
R: $R$. solanacearum only -
E: Ethanol only 


\section{Effect of two algae on disease severity under artificial inoculation condition:}

From Table (2) can concluded that AUDPC and disease severity were decreased in all algae treatments (ranged from 1 to 9.7) compared with $R$. solanacearum treatment (positive control, 24.5). The least AUDPC recorded when used $P$. pavonica and $T$. decurrens at concentration $2 \mathrm{ml} / 250 \mathrm{ml}$ in the water and ethanol extractions (1, 1.3, 1.2 and 1.5) respectively followed by the other concentration (2, 5.6, 7.8 and 9.7) respectively. In all treatments AUDPC recoded significant differences with positive control. But, non- significant differences showed between all algae extractions uses at concentration $1 \mathrm{ml} / 250 \mathrm{ml}$ (ranged 2 to 9.7) except $P$. pavonica (water extraction, 2). Also, all treatments at $2 \mathrm{ml} / 250 \mathrm{ml}$ (ranged 1 to 1.5 ) and $P$. pavonica water extraction didn't show any significant differences among them.

Table (2): Effect of $T$. decurrens and $P$. pavonica algae as water and ethanol extracted on brown rot disease development in pots experiment.

\begin{tabular}{|c|c|c|c|c|}
\hline Extraction & Algae & $\begin{array}{c}\text { Concentration } \\
(\mathrm{ml} / 250 \mathrm{ml} \text { water })\end{array}$ & AUDPC $^{*}$ & $\begin{array}{c}\text { Disease } \\
\text { Severity }(\%) \\
\end{array}$ \\
\hline \multirow{4}{*}{ Ethanol } & \multirow{2}{*}{$P$. pavonica } & 1 & $7.8 \mathrm{~b}$ & 48 ab \\
\hline & & 2 & $1.2 \mathrm{c}$ & $12 \mathrm{~cd}$ \\
\hline & \multirow{2}{*}{ T. decurrens } & 1 & $9.7 \mathrm{~b}$ & $54 \mathrm{ab}$ \\
\hline & & 2 & $1.5 \mathrm{c}$ & $14 \mathrm{~cd}$ \\
\hline \multirow{4}{*}{ Water } & \multirow{2}{*}{$P$. pavonica } & 1 & $2 \mathrm{c}$ & $16 \mathrm{bcd}$ \\
\hline & & 2 & $1 \mathrm{c}$ & $8 \mathrm{~d}$ \\
\hline & \multirow{2}{*}{ T. decurrens } & 1 & $5.6 \mathrm{~b}$ & 28 abc \\
\hline & & 2 & $1.3 \mathrm{c}$ & $10 \mathrm{~d}$ \\
\hline \multicolumn{3}{|c|}{ Control + } & $24.5 \mathrm{a}$ & 98 a \\
\hline
\end{tabular}

\section{* Area Under Disease Progress Curve}

On the other hand, data in the same Table indicated the decreased of disease severity in all treatments (ranged $8 \%$ to 48\%) compared with positive control (98\%). The treatment with water extraction of $P$. pavonica followed by $T$. decurrens recorded the least disease severity 8 
and $10 \%$ when uses at concentration $2 \mathrm{ml} / 250 \mathrm{ml}$ respectively. Then, followed by treatment with ethanol extraction of $P$. pavonica and $T$. decurrens 12 and $14 \%$ at the same concentration.

At concentration $1 \mathrm{ml} / 250 \mathrm{ml}$ of algae the disease severity were 16 , 28, 48 and 54\% when used $P$. pavonica and $T$. decurrens extracted by water and ethanol respectively. No significant differences showed in all treatment when using two extractions of two algae at $1 \mathrm{ml}$ concentration, also no significant differences recorded among all treatment at the same concentration and positive control. However, significant differences showed among all treatments at concentration $2 \mathrm{ml}$ and positive control, and also among these treatments and the treatments at concentration $1 \mathrm{ml}$ except treatment with $P$. pavonica water extraction.

\section{Total and free phenolic quantity:}

Data in Table (3) revealed that algae were extracted by water have high amount of total and free phenols compared with algae were extracted by ethanol. The highest one algae is $P$. pavonica (water extraction) in total and free phenols 3.070 and $2.193 \mathrm{mg} / \mathrm{ml}$ respectively, followed by $T$. decurrens (water extraction) and P. pavonica (ethanol extraction) 2.516, $1.596,1.891$ and $1.316 \mathrm{mg} / \mathrm{ml}$ respectively. While, the least one algae $T$. decurrens (ethanol extraction) were 1.431 and $1.287 \mathrm{mg} / \mathrm{ml}$.

Table (3): The quantity of total and free phenolic compounds in two extractions algae.

\begin{tabular}{|c|c|c|c|}
\hline \multirow{3}{*}{ Extractions } & \multirow{2}{*}{ Algae } & \multicolumn{2}{|c|}{$\begin{array}{c}\text { PHENOLIC COMPUNDS } \\
(\mathbf{m g} / \mathbf{m l})\end{array}$} \\
\cline { 3 - 4 } & & TOTAL & FREE \\
\hline \multirow{2}{*}{ Ethanol } & $P$. pavonica & 1.891 & 1.316 \\
\cline { 2 - 4 } & $T$. decurrens & 1.431 & 1.287 \\
\hline \multirow{2}{*}{ Water } & P. pavonica & 3.070 & 2.193 \\
\cline { 2 - 4 } & $T$. decurrens & 2.516 & 1.596 \\
\hline
\end{tabular}




\section{$\underline{\text { Discussion }}$}

Ralstonia solanacearumis causing bacterial wilt disease in hundreds of economic plants from different families. This pathogen is affects the exportation of potato crop, to the European markets and that lead to lose a lot of money (Kabeil et al., 2008). Methods of controlling $R$. solanacearum due to its abilities to grow endophytically, survive in soil, especially in the deeper layers, travel along water, and its relationship with weeds. So, Yuliar et al., (2015) discuses different methods to control the diseases caused by $R$. solanacearum like uses of antioxidants (Farag et al., 2017), and cyanobacteria (Mikhail et al., 2016) to shows some solutions. In recent year, seaweeds are used in several applications such as anti-microbial (Chiheb et al., 2011) and produce a large number of antibacterial and antifungal materials, also they almost never threaten the environment (Kulik, 1995) . In Egypt, Farag et al., (2017) proved the suppression effect of seaweed extract (SWE) on $R$. solanacearum whereas increase nutrient uptake and improve crop productivity.

Brown algae have some of the valuable medicinal components such as: Anti-biotics and anti-oxidant, and most of the compounds of brown seaweeds show anti-bacterial activities (Mtolera and Semesi, 1996 and Blunt, 2006).

Algae extracted by water have the largest inhibition zone at the two concentrations used $(1$ and $2 \mathrm{ml} / 250 \mathrm{ml})$, in two algae ( $P$. pavonica and T. decurrens) respectively. Followed by Ethanol extractions at the same previously arrangement. The inhibition zone refers to the marine algae especially brown algae antibacterial activity. Whereas, marine algae are the largest producers of biomass in the marine environment, they produce 
a wide variety of chemically active metabolites in their surroundings. These active metabolites, also known as biogenic compounds, produced by several species of marine macro and micro algae, have anti-bacterial and anti-fungal properties and many marine algal have bioactive compounds, some of these compounds are sterols, Polysaccharides, peptides, proteins, vitamins, phenols and alkanes (Bhadury and Wright, 2004., Elsayed et al., 2012., Abdel-Raouf et al., 2015).

In pots experiment, the extraction by water in two algae was more effective in the two concentrations were used compared with extraction by ethanol, and $P$. pavonica algae was effectiveness compared with $T$. decurrens algae. The amount of phenols contains from any algae depending on the extracted solvent uses, which make variation between the effects of algae in the different extraction (El-Shazoly and Fawzy 2018., and Naja et al., 2012)

Quantities of total and free phenols extraction from two algae were different. The highest amount of them was $P$. pavonica extracted by water followed by $T$. decurrens and $P$. pavonica extracted by ethanol and the last one $T$. decurrens respectively. These differences among the phenols amount in each alga certain the differences between $P$. pavonica and $T$. decurrens to inhibit the growth and development of $R$. solanacearum. Whereas, Different extracts of the Turbinaria shows the presence of alkaloids, phenols, tannins and flavonoids, It is used as antimicrobial, antioxidant, antifungal, antiulcer, antitumor and antibacterial (Raj Kumar and Bhavan, 2017). But, Turbinaria species has a low level of phenolic and tannins compounds (Bittick et al., 2009), this level depending on the solvent used in the extraction (Sami. et al., 2019). 
However, $P$. pavonica has been important algae, extensively used as a feedstock for the production of bio-diesel, in heavy-metal biosorption, as a pollution bio-indicator, a trace metal bio-monitor, an anti-oxidant, an anti-cancer drug (by inducing apoptosis of cancer cells), an anti-bacterial agent and a bio-insecticide (El Maghraby and Fakhry, 2014). Also, the highest amount of phenolic compound was found in the extract obtained from $P$. pavonica this extract also showed the highest antioxidant activity (Hamza et al., 2014 and Naja et al., 2012). 


\section{$\underline{\text { References }}$}

Abdel-Raouf, N.; N.M. Al-Enazi; A.A. Al-Homaidan; I.B.M. Ibraheem; M.R. Al-Othman and A.A. Hatamleh (2015). Antibacterial $\beta$-amyrin isolated from Laurencia microcladia. Arabian Journal of Chemistry, 8(1): 32-37.

Bhadury, P. and C.P. Wright (2004). Exploitation of marine algae: biogenic compounds for potential antifouling applications. Planta, 219: 561-578.

Bittick, S. J.; N.D. Bilotti; H.A. Peterson and H.L. Stewart (2009). Turbinaria ornata as an herbivory refuge for associate algae. Marine Biology., 157(2): 317-323.

Blunt, J.W. (2006). Marine Natural Products. Natural Product Report, 23: 26-78.

Chiheb, I. Riadi; H. Martine -Lopez; J. Dominguez-Seglar; J.F. Gomez-Vidal; J.A. Bouziane and H.M. Kadiri (2011). Screeening of antibacterial activity in marine green and brown macroalgae from the coast of Morocco. In African Journal of Biotechnology, 8: 1258-1562.

Deepak, k.P.; R. Sowmiya; G. Balasubramani and P. Perumal (2017). Phytochemical profiling of Turbinaria ornata and its antioxidant and anti-proliferative effects. Journal of Taibah University Medical Sciences., 12: 329-337.

Duncan, D.B. (1955). Multiple range and multiple F test. Biometrics, 11: $1-42$.

El Maghraby, D.M. and E.M. Fakhry (2014). Lipid content and fatty acid composition of Mediterranean macro-algae as dynamic factors for biodiesel production.Oceanologia, 57: 86-92. 
Elsayed, K.N.; M.M. Radwan.; S.H. Hassan.; M.S. Abdelhameed; I.B. Ibraheem and S.A. Ross (2012). Phytochemical and biological studies on some Egyptian seaweeds. Nat. Prod. Commun.,7: 1209-1210.

El-Shazoly, M. Rasha and M. A. Fawzy (2018). Biochemical composition and antioxidant properties of some seaweeds from Red Sea coast, Egypt. European Journal of Biological Research, 8 (4): 232-242.

Farag, S.M.A.; K.M.A. Elhalag; M.H. Hagag; A.M. Khairy; H.M. Ibrahim; M.T. Saker and N.A.S. Messiha (2017). Potato bacterial wilt suppression and plant health improvement after application of different antioxidants. Journal of Phytopathology 165:522-537.

Gomez, K.A. and A.A. Gomez (1984). Statistical Procedures for Agricultural Research. 2nd Edition, John Wiley and Sons, New York.

Hamza, H. Amal; Widad, Al-Bishri; H.H. Omar and Enas N. Danial (2014). Potential Antimicrobial, Antioxidant and Anityrosenase Activities achieved by Selected Species of Marine Macroalgae. Journal of Pure and Applied Microbiology, 8: 257-265

Hayward, A.C. (1991). Biology and epidemiology of bacterial wilt caused by Pseudomonas solanacearum.Annu Rev Phytopathol 29: 65-87.

Kabeil, S.S.; M.A. Amer Matar and M.H. El- Masry (2008). In Planta: Biological control of potato brown rot disease in Egypt. World $\mathbf{J}$ Agric Sci., 4(S): 803-810.

Kulik, M. (1995). The potential for using cyanobacteria (blue-green algae) and algae in the biological control of plant pathogenic bacteria and fungi.Eurp. J. plant path., 101(6): 585-599.

Messiha, N.A.S. (2006). Bacterial wilt of potato (Ralstonia solanacearum race 3, biovar2): Disease management, pathogen survival and possible eradication. PhD thesis Wageningen University, The Netherlands. 
Mikhail, M.S.; B.A. Hussein; N.A.S. Messiha; K.M.M. Morsy and

M.M.Youssef (2016). Using of Cyanobacteria in controlling potato brown rot disease. International Journal of Scientific \& Engineering Research, 7: 274-281.

Mtolera, M.S.P. and A.K. Semesi (1996). Antimicrobial activity of extracts from six green algae from Tanzania. Current Trends in Marine Botanical Research in the East African Region, SIDA, pp: 211-217.

Naja. K, Mawlawi Hiba and Chbani Asma (2012). Antioxidant and Antifungal activities of Padina Pavonica and Sargassum Vulgare from the Lebanese Mediterranean Coast. Advances in Environmental Biology, 6(1): 42-48.

Pérez, M.; Falqué and E.H. Domínguez, (2016). Antimicrobial Action of Compounds from Marine Seaweed. Marine Drugs, 14(3): 52.

Rajkumar, G. and P. S. Bhavan. (2017). Phytochemical characterization of the marine brown alga Turbinaria ornate. Research Journal of Chemistry and Environment., 21(3): 54-63.

Sami, F. J.; N. H. Soekamto; Firdaus and J. Latip (2019). Total phenolic, antioxidant activity and toxicity effect of Turbinaria decurrens extracts from South Sulawesi. Journal of Physics: Conference Series. 1341.

Simons, T. J. and A. F. Ross (1971). Changes in metabolism associated with enclosed systemic resistance to tobacco. Phytopathology. 61: 12611265.

Shoala, T. and Rabab. M. Abd-El-Aziz (2019). Silver and Magnetic Iron Oxide Nanoparticles-Assisted PCR for the Phytopathogenic Bacteria Ralstonia solanacearum. J. of Plant Protection and Pathology, Mansoura Univ., 10 (9):471-476. 
Stonier, T. (1960). Agrobacterium tumefaciens Conn. II. Production of an antibiotic substance. J. Bact. 79: 889-898.

Winstead, N.N. and A. Kelman (1952). Inoculation techniques for evaluating resistance to Pseudomonas solanacearum. Phytopathology: 42:628-634.

Yuliar. A.; N. Yanetri and T. Koki (2015). Recent Trends in Control

Methods for Bacterial Wilt Diseases Caused by Ralstonia solanacearum.

Microbes Environ. 30(1): 1-11. 


\section{استخدام الطحالب البنية بادينا باقونيكا و توربيناريا ديكيرينس لمقاومة مرض العفن البنى البكتيري \\ رباب محمد عبد العزيز}

قسم بحوث الامراض البكتيريةـ معهد بحوث أمراض النباتاتـ مركز البحوث الزراعيةـ الجيزةـ مصر.

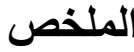

تعتبر الطحالب البنية من أهم مصادر المقاومة الحيوية لما تحتويه من مو اد حيوية نشطة عديدة. وقد استخدمت مستخلصات الطحلبين بادينا باقونيكا و توربيناريا ديكيرينس فى الماء و الكحول الايثيلى لدر اسة تأثير هما المضاد على تقدم مرض العفن البنى فى المعمل وتحت ظروف العدوى الصناعية. وقد استطاع هذان الطحلبان ثتيط نمو البكثيريا رالستونيا سولاناسيرم فى المعمل. و اعطى المستخلص المائى للطحلب بادينا باقو نيكا عند استخدامه أعلى منطقة تثيط للبكتيريا بينما كان الاقل تثبيطاً المستخلص الكحولى للطحلب توربيناريا ديكيرينس. و انخفضت الثدة المرضية ومنحنى تقدم المرض فى جميع المعاملات النباتية بمستخلصات الطحلبين مقارنة بالمعاملة الموجبة للمرض. ووجد ان كمية الفينو لات الكلية والحرة فى مستخلصات بادينا باقونيكا أكبر من كميتها فى توربيناريا ديكيرينس. وقد أثرت المو اد المستخدمة فى الاستخلاص وكمية الفينو لات الكلية والحرة على قدرة الطحالب على وقف تقدم الرالستونيا سولاناسيرم وخفض شدتها المرضية. وكان الطحلب بادينا باثونيكا أكثر كفاءة فى مقاومة مرض العفن البنى معمليا وتحت ظروف العدوى الصناعية. لذلك نهدف لزيادة الدراسة لتعريف المركبات الفينولية الخاصة و المسئولة عن زيادة التأثير المضاد للبكتيريا وايضا محاولة تطبيق استخدام الطحالب في مقاومة الأمر اض النباتية. 